GLOBAL WATER PATHOGEN PROJECT

PART FOUR. MANAGEMENT OF RISK FROM EXCRETA AND WASTEWATER

\title{
CONSTRUCTED WETLANDS
}

\author{
Ynoussa Maiga \\ University of Ouagadougou \\ Ouagadougou, Burkina Faso
}

\section{Marcos von Sperling}

Federal University of Minas Gerais

Belo Horizonte, Brazil

\section{James Mihelcic}

University of South Florida

Tampa, United States 


\section{Copyright:}

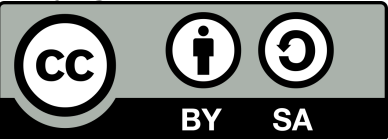

This publication is available in Open Access under the Attribution-ShareAlike 3.0 IGO (CC-BY-SA 3.0 IGO) license (http://creativecommons.org/licenses/by-sa/3.0/igo). By using the content of this publication, the users accept to be bound by the terms of use of the UNESCO Open Access Repository (http://www.unesco.org/openaccess/terms-use-ccbysa-en).

\section{Disclaimer:}

The designations employed and the presentation of material throughout this publication do not imply the expression of any opinion whatsoever on the part of UNESCO concerning the legal status of any country, territory, city or area or of its authorities, or concerning the delimitation of its frontiers or boundaries. The ideas and opinions expressed in this publication are those of the authors; they are not necessarily those of UNESCO and do not commit the Organization.

\section{Citation:}

Maiga, Y., von Sperling, M. and Mihelcic, J.R. (2017). Constructed Wetlands. In: J.B. Rose and B. Jiménez-Cisneros (eds), Water and Sanitation for the 21st Century: Health and Microbiological Aspects of Excreta and Wastewater Management (Global Water Pathogen Project). (J.R. Mihelcic and M.E. Verbyla (eds), Part 4: Management Of Risk from Excreta and Wastewater - Section: Sanitation System

Technologies, Pathogen Reduction in Sewered System Technologies), Michigan State University, E. Lansing, MI, UNESCO. https://doi.org/10.14321/waterpathogens.66

Acknowledgements: K.R.L. Young, Project Design editor; Website Design: Agroknow (http://www.agroknow.com)

Last published: March 22, 2017 


\section{Summary}

Constructed wetlands are a sanitation technology that utilize natural removal mechanisms provided by plant vegetation, soil, and associated microbial populations. The type of wetland can be distinguished according to criteria such as presence/absence of free water surface, use of rooted emergent aquatic plants (or free floating plants), and direction of flow. The three types of constructed wetlands discussed in this chapter are: 1) horizontal subsurface flow constructed wetlands, 2) horizontal free water surface flow constructed wetlands, and 3) vertical flow constructed wetlands. Constructed wetlands have been used to treat both centralized and on-site wastewater. Primary treatment is recommended when there is a large amount of suspended solids or soluble organic matter (measured as BOD and COD). This can be accomplished by placing sanitation technologies such as screening and grit removal, followed by a septic tank or primary sedimentation, waste stabilization pond, or anaerobic reactor prior to the wetland. All types of pathogens are expected to be removed in a constructed wetland; however, greater pathogen removal is expected to occur in a subsurface wetland. In a free water surface flow wetland one can expect 1 to $2 \log _{10}$ reduction of pathogens; however, bacteria and virus removal may be $<1 \log _{10}$ reduction in systems that are heavily planted with vegetation. This is because constructed wetlands typically include vegetation which assists in removing other pollutants such as nitrogen and phosphorus. Therefore, the importance of sunlight exposure in removing viruses and bacteria is minimized in these systems. Removal in a properly designed and operated free water surface flow wetland is reported to be $<1$ to $2 \log _{10}$ for bacteria, $<1$ to
$2 \log _{10}$ for viruses, 1 to $2 \log _{10}$ for protozoa:, and 1 to $2 \log _{10}$ for helminths. In subsurface flow wetlands, the expected removal is pathogens is reported to be 1 to $3 \log _{10}$ for bacteria, 1 to $2 \log _{10}$ for viruses, $2 \log 10$ for protozoa, and 2 $\log _{10}$ for helminths.

\section{Constructed Wetlands}

\subsection{Brief Technology Description}

Constructed wetlands are designed and constructed to remove water pollutants by utilizing natural removal mechanisms provided by plant vegetation, soil, and associated microbial populations (ITRC, 2003). The type of wetland can be distinguished according to criteria such as presence/absence of free water surface, use of rooted emergent aquatic plants (or free floating plants), and direction of flow (Vymazal, 2008). The three types of constructed wetlands discussed here are: 1) horizontal subsurface flow constructed wetlands (Figures 1-2), 2) horizontal free water surface flow constructed wetlands (Figures 3-4), and 3) vertical flow constructed wetlands (Figure 5). Table 1 compares these wetlands types in terms of the direction of flow and types of aquatic vegetation that might be observed. Most constructed wetlands have plants that are rooted into the underlying soil/sediment though as discussed in this table and shown in Figure $4 \mathrm{~b}$, plants can also be free-floating, floating-leafed, or submerged. wetlands are unique in the sense that they can provide other economic and societal benefits associated with expanded green space (Wright Wendel et al., 2011).

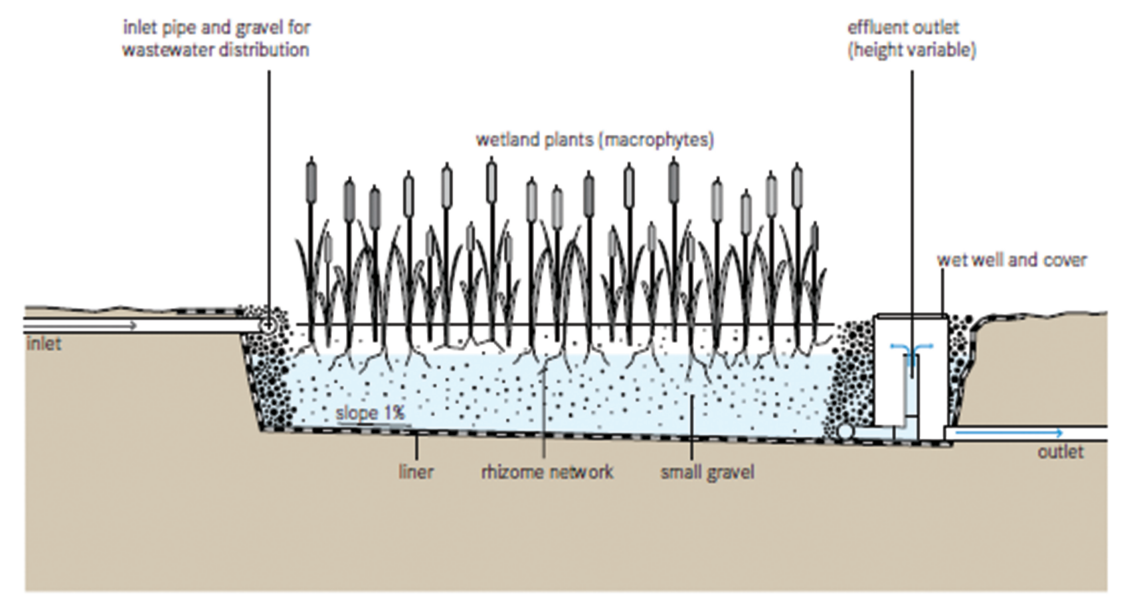

Figure 1. Horizontal subsurface flow constructed wetland (reprinted with permission of Eawag: Swiss Federal Institute of Aquatic Science and Technology Department Water and Sanitation in Developing Countries (Sandec). Figure from Tilley, E., Ulrich, L., Lüthi, C., Reymond, Ph. and Zurbrügg, C., 2014. Compendium of Sanitation Systems and Technologies. 2nd Revised Edition. Swiss Federal Institute of Aquatic Science and Technology (Eawag). Dübendorf, Switzerland). 


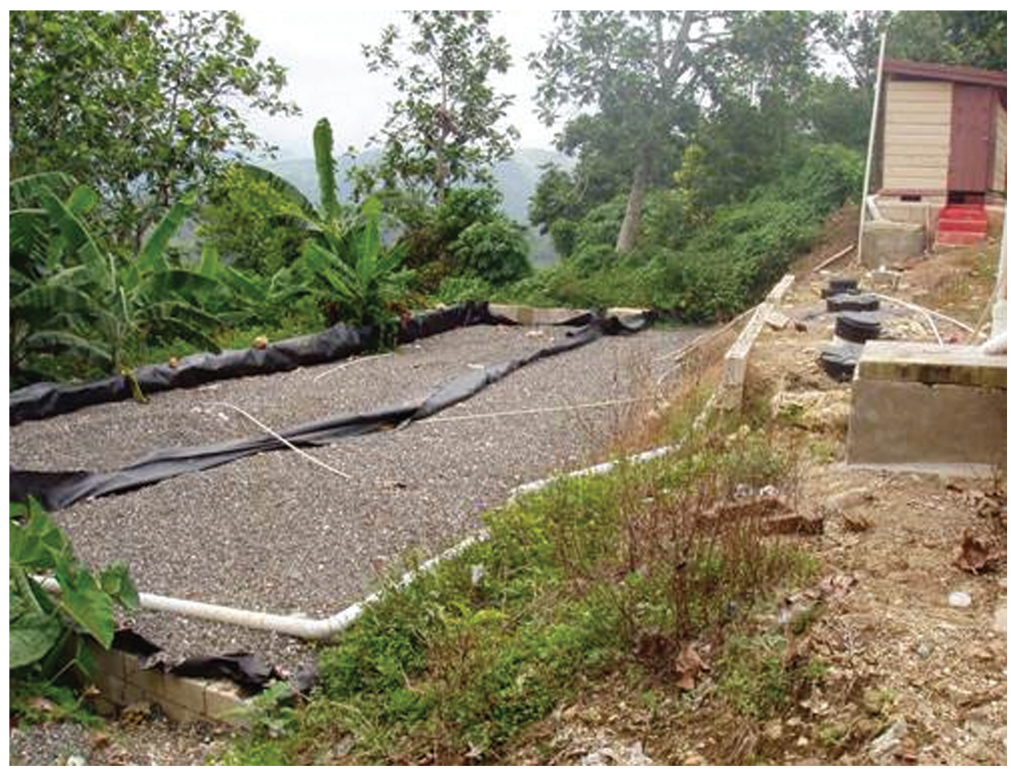

Figure 2. Two horizontal subsurface flow constructed wetlands (plants not yet planted) in parallel that treat septic tank effluent produced by a primary school in Jamaica (photo reproduced with permission from Edward Stewart (2005))

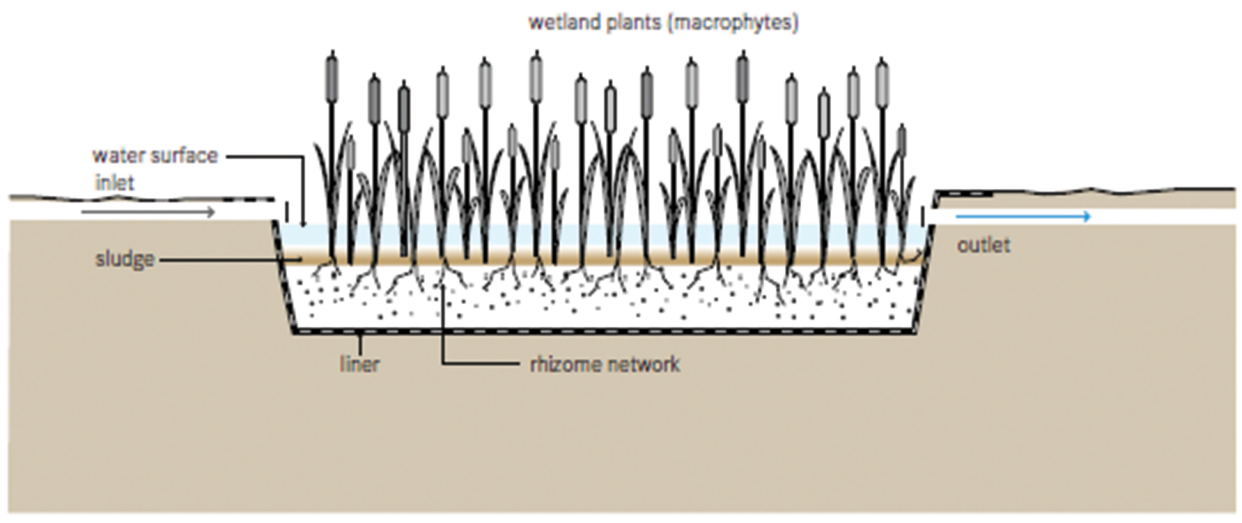

Figure 3. Free water surface flow constructed wetland (reprinted with permission of Eawag: Swiss Federal Institute of Aquatic Science and Technology Department Water and Sanitation in Developing Countries (Sandec). Figure from Tilley, E., Ulrich, L., Lüthi, C., Reymond, Ph. and Zurbrügg, C., 2014. Compendium of Sanitation Systems and Technologies. 2nd Revised Edition. Swiss Federal Institute ofAquatic Science and Technology (Eawag). Dübendorf, Switzerland) 


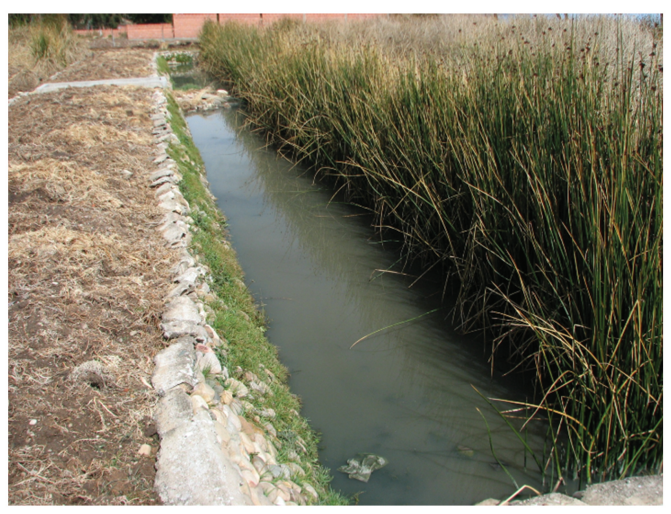

(a)

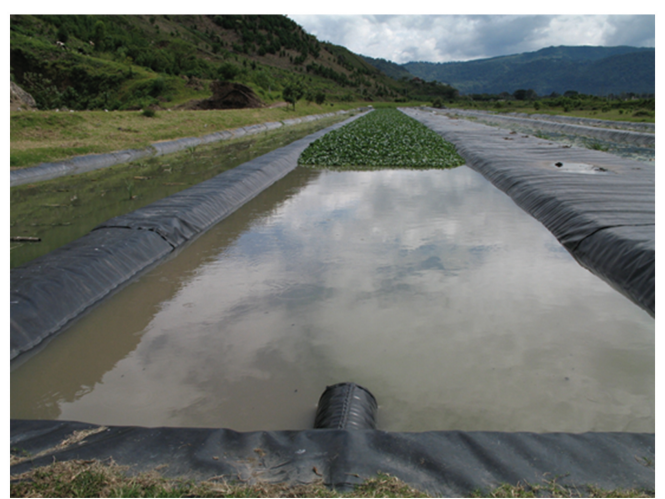

(b)

Figure 4. (a). Free water surface flow constructed wetland in Copacabana, Bolivia (photo reproduced with permission from Stewart Oakley). (b) An experimental water surface flow constructed wetland that does not contain media and is planted with water hyacinths, Guatemala City (photo reproduced with permission from Stewart Oakley). The experimental wetland in $4 \mathrm{~b}$ is by definition considered a free-floating plant system because it does not contain rooted emergent plants like the free surface wetland pictured in $4 \mathrm{a}$. Water hyacinth is an aquatic plant native to the Amazon basin and can be a problematic invasive species if released to the natural environment outside its native range.

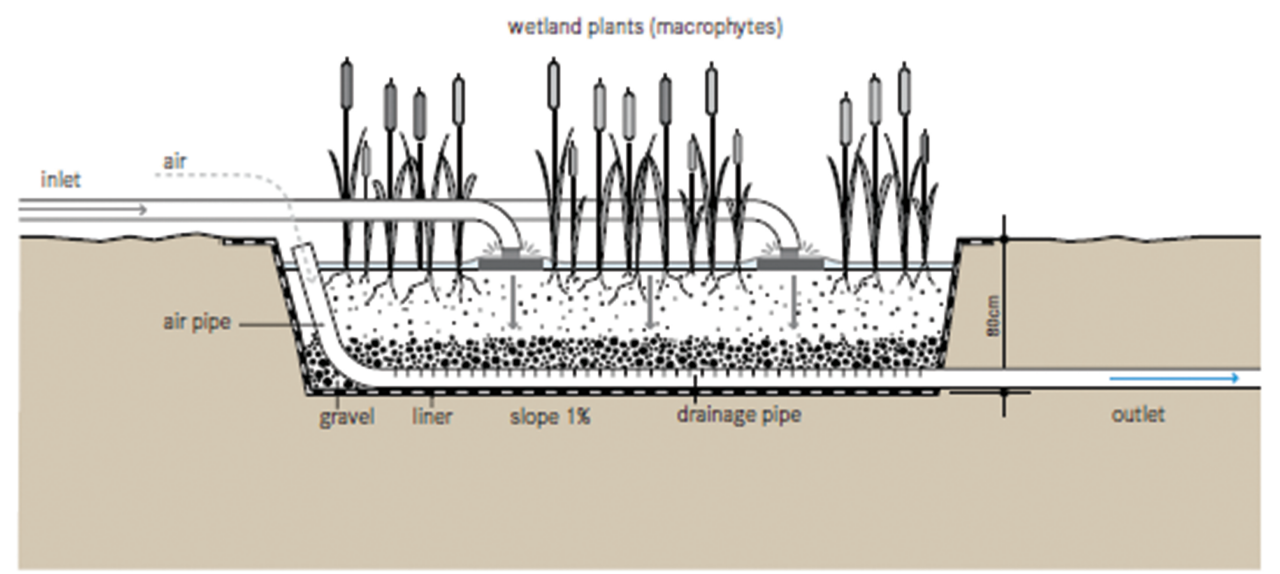

Figure 5. Vertical flow wetland run for operation in a downflow hydraulic regime (reprinted with permission of Eawag: Swiss Federal Institute of Aquatic Science and Technology Department Water and Sanitation in Developing Countries (Sandec). Figure from Tilley, E., Ulrich, L., Lüthi, C., Reymond, Ph. and Zurbrügg, C., 2014. Compendium of Sanitation Systems and Technologies. 2nd Revised Edition. Swiss Federal Institute of Aquatic Science and Technology (Eawag). Dübendorf, Switzerland) 
Table 1. Types of constructed wetlands for wastewater treatment (Adapted from Vymazal, 2008)

\begin{tabular}{lcc}
\hline Wetland Type & Free Water Surface Flow & Subsurface Flow \\
\hline Type of Plants & $\begin{array}{c}\text { Free-floating, floating-leafed, } \\
\text { submerged, emergent }\end{array}$ & Emergent only \\
\hline Direction of Flow & Horizontal & Horizontal or Vertical (vertical can \\
be downflow or upflow)
\end{tabular}

In the subsurface flow configuration (Figures 1 and 5), water flows through the media and below the surface. The direction of the flow in a subsurface wetland can be either horizontal or vertical. In this case, there is little, if any visible water, especially for the subsurface wetland designed for horizontal flow. As shown in Figure 1, a horizontal subsurface flow constructed wetland is a basin (that can be lined) that consists of porous media such as large gravel or sand. It is also planted with wetland vegetation (Tilley et al., 2014). A vertical downflow subsurface constructed wetland is a planted filter bed (again with porous media) that is typically drained at the bottom (Figure 5). Wastewater is poured or dosed below the surface, or onto the surface, from above using a mechanical dosing system. The water flows vertically down through the filter matrix to the bottom of the basin where it is collected in a drainage pipe.

An important difference between a vertical and a horizontal flow subsurface wetland is not simply the direction of the flow path, but rather the resulting redox environment (Tilley et al., 2014). For example, the downflow hydraulic regime of a vertical subsurface wetland system receiving pulse feedings will promote the presence of aerobic conditions because the media stays unsaturated. For those considering nutrient management, this will promote biological transformation of nitrogen present as ammonia $\left(\mathrm{NH}_{4}^{+} / \mathrm{NH}_{3}\right)$ to nitrate $\left(\mathrm{NO}_{3}{ }^{-}\right)$. If this downward flow regime is followed by a second vertical flow constructed wetland operated in an upflow hydraulic regime, anoxic conditions can be obtained in the upflow zone because the media in this cell will remain saturated. This is required for further transformation of nitrogen and its subsequent removal from the water phase, from nitrate $\left(\mathrm{NO}_{3}{ }^{-}\right)$to nitrogen gas $\left(\mathrm{N}_{2}\right)$ (Fuchs et al., 2012).
Surface flow wetlands systems consist of plants grown in porous media or sediments and will have the visible presence of water which is typically 0.15 to $0.60 \mathrm{~m}$ in depth (Quinonez-Diaz et al., 2001; Mihelcic and Zimmerman, 2014). In these systems, the water surface of the wetland is exposed to the atmosphere which can theoretically provide oxygen to the water and also UV disinfection.

For more information about the design of constructed wetlands, refer to Crites and Tchobanoglous (1998), US EPA (1988), Kadlec and Knight (1996), Vymazal and Kröpfelová (2008), Kadlec and Wallace (2009) and Mihelcic et al. (2009). A review of pathogen fate in constructed wetlands is provided by Wu et al. (2016).

Figure 6 shows the location a constructed wetland in the sanitation service chain. In terms of wastewater treatment, constructed wetlands can be placed at the end of the overall engineered wastewater treatment system. This set of unit processes can include: 1) preliminary treatment with a bar screen and grit chamber that is followed by flow measurement and 2) another treatment unit process such as primary sedimentation basin, septic tank, waste stabilization pond, or anaerobic reactor (von Sperling, 2007). 


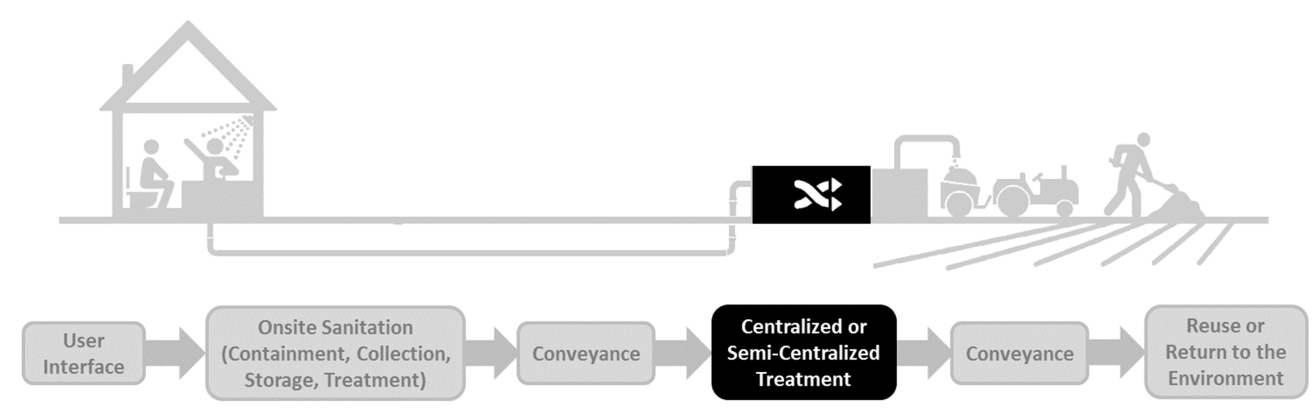

Figure 6. Locations where constructed wetlands are used within the sanitation service chain

\subsection{Inputs and Outputs}

Constructed wetlands have been used to treat on-site and centralized collected wastewater (Decamp and Warren, 2000; Stewart, 2005), septage (Koottatep et al., 2005), greywater (Morel and Diener, 2006), stormwater runoff (Tanner et al., 2005), organic waste streams (Cronk, 1996), agricultural wastewater (Kantawanichkul and Somprasert, 2005), landfill leachate (Headley et al., 2004), acid mine drainage (Batty et al., 2005), and food processing and tannery wastewaters (Burgoon et al., 1999; Calheiros et al., 2007). Pre-treatment is recommended for waste streams such as domestic wastewater when there is a large amount of particulate matter (i.e., suspended solids) or organic matter (i.e., COD, BOD) (Cronk, 1996, Williams et al., 1999). This can be accomplished by placing screening and grit removal, followed by a septic tank or primary sedimentation, waste stabilization pond, or anaerobic reactor prior to the wetland.

The typical inputs for a constructed wetland are shown in Figure 7. Typical concentrations of pathogens in these inputs depend on the treated effluent from previous treatment stages described in other chapters that are specific to other sanitation technologies. Outputs from constructed wetlands can include treated effluents, sediments accumulated on the top of vertical systems, and harvested plants.

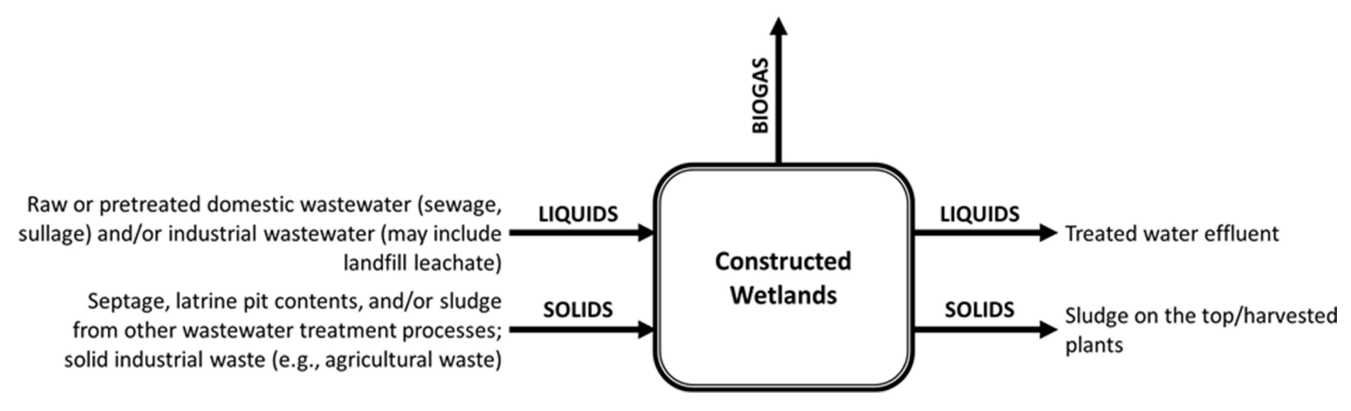

Figure 7. Typical inputs and outputs for constructed wetlands

\subsection{Factors Affecting Pathogens in Constructed Wetlands}

As discussed in the chapter on Waste Stabilization Ponds, pathogens are removed from the wastewater or inactivated by a variety of different mechanisms that occur at different rates. The effectiveness of these removal mechanisms is dependent on a number of environmental, design, and operational factors. These different factors are observed to affect different pathogens in different ways.

In a constructed wetland, bacterial, viral, protozoan and helminth pathogens and indicator species are removed or inactivated through a complex combination of physical/ chemical and biological (i.e., microbial/phytological) factors (ITRC, 2003; Kuschk et al., 2012). The primary mechanism(s) of removal will be different for free water surface and subsurface flow wetlands. Important for all these removal/inactivation mechanisms is they may occur to a greater extent in different zones of the free surface constructed wetland. For example, the three zones of a free water surface flow wetland are shown in Figure 8. Note that the zones differ in terms of their level of oxygen concentration, depth, and amount of planted vegetation (Mihelcic et al., 2009). All these can impact the physical-chemical and biological processes that control pathogen fate. 


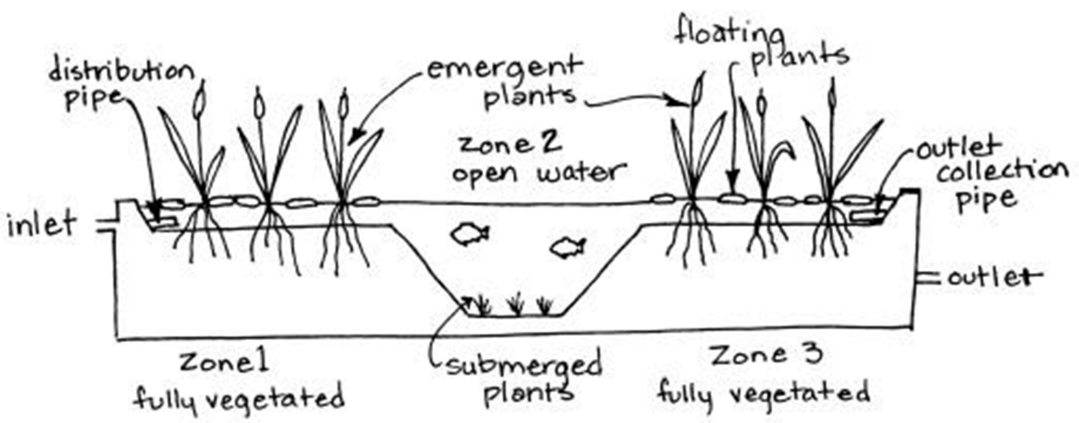

\section{Figure 8. Three zones of a free water surface flow wetlands (reprinted from Mihelcic et al., 2009, with permission of Linda D. Phillips)}

The most important factor for the removal of viral and bacterial pathogens is sunlight exposure, although other factors such as temperature and $\mathrm{pH}$ are also important. Because constructed wetlands include vegetation (which assists in removing other pollutants such as nutrients), the importance of sunlight exposure is minimized in these systems. Thus, one would expect that viral and bacterial pathogens are not removed as well as in a shallow, clear, open pond. Again, as with waste stabilization ponds, sedimentation is believed to be the most important factor for the removal of protozoan pathogens and helminth eggs. Different pathogen types are also not necessarily removed at the same rate by a similar mechanism. For example, it was stated in the Waste Stabilization Pond chapter that viruses are generally more resistant than bacteria to removal from sunlight mediated reactions (Davies-Colley et al., 2005a; Sinton et al., 2002) and differences in their structural and genetic composition impacts the rate of removal (Silverman et al. 2013; Mattle et al. 2014; Kohn et al. 2016).
Important factors expected to influence pathogen removal include mechanical filtration, temperature, adsorption to organic matter, and adhesion to biofilm. Other removal mechanisms include exposure of pathogens to biocides excreted by some wetland plants, the antimicrobial activity of root excretions, and predation by nematodes and protists, (e.g., Cronk, 1996; Gerba et al., 2000; Vymazal, 2005; Kusch et al., 2012; Wu et al., 2016). Table 2 provides a summary of some of the important pathogen removal mechanisms in constructed wetlands and how these mechanisms may differ in a free water surface flow and subsurface flow wetland.

Table 2. Major removal mechanisms of pathogen inactivation in free and subsurface wetlands

Removal or Inactivation Mechanism

Free Water Surface Flow Wetland

Process is very important for virus inactivation. The presence of vegetation will limit pathogen exposure

Sunlight

Plants

Mechanical

Filtration and

Adsorption

Temperature to sunlight. If part of the wetland is free of vegetation, removal will depend on water depth, water clarity, dissolved oxygen concentration, and geographical location.

Believed to be more important for larger organisms such as protozoan (oo)cysts and helminth eggs. Bacteria and viruses will not settle unless they are attached to larger and denser particles.

Planted systems reduce sunlight exposure which lowers virus and bacteria removal. However, plants support other pathogen removal mechanisms such as filtration, adsorption, and secretion of biocides.

Can occur in porous media that vegetation is planted in.

Plants provide shading and may cause surface water to be cooler than in an open pond.
Subsurface Wetlands

Not applicable

Not applicable

Planted systems are expected to exhibit greater pathogen removal. Plants support removal mechanisms such as filtration, adsorption and secretion of biocides.

Process is a primary pathogen removal mechanism, particularly for helminth eggs and larger protozoan (oo)cysts and some bacteria.

May moderate extreme cold temperatures encountered during winter operation. 


\subsection{Sunlight and Water Clarity}

Solar disinfection can probably only take place in a free water surface flow wetland that has some area that is not planted with emergent or floating vegetation. This is because, as stated previously, the presence of vegetation will limit pathogen exposure to sunlight. This is important because solar inactivation is probably the most important mechanism for virus inactivation. As discussed in the Waste Stabilization Pond chapter, the "UV portion of sunlight directly damages pathogen genomes (photo-biological damage)" and "UV and visible wavelengths can react with photosensitizers (such as natural organic matter) or photosensitizer molecules within bacteria (such as $\mathrm{NADH} / \mathrm{NADPH}$, flavins, and porphyrins) to produce reactive species that indirectly damage pathogens (photo-oxidative damage). Sunlight is stronger at lower latitudes, higher elevations, and in locations with less cloud cover." Sunlight is also rapidly attenuated within the first few centimeters of a pond-like system that contains wastewater or natural organic matter (Davies-Colley et al., 2005b). The issue of sunlight exposure in a planted system is especially important because there is a direct relationship between the amount of sunlight that reaches a pathogen and the inactivation rate (Nguyen et al. 2015; Silverman et al. 2015). The inactivation of viruses by sunlight and the influence that different parts of the solar spectrum have on different viral species is discussed by Silverman et al. (2013).

For horizontal subsurface flow and vertical subsurface flow constructed wetlands, the influence of solar intensity is not existent because the wastewater is primarily contained below the ground surface. A free surface flow constructed wetland which has some open areas without vegetation (e.g., zone 2 in Figure 8 and the front part of the experimental wetland in Figure $4 \mathrm{~b}$ ) can allow for pathogen exposure to sunlight. UV-B (280 -320 nm), UV-A (320-400 $\mathrm{nm}$ ) and photosynthetically active radiation (PAR $>400$ $\mathrm{nm}$ ) of the solar spectrum are known to be responsible for inactivating indicator microorganisms (Muela et al., 2000; Sinton et al., 2002; Kadir and Nelson, 2014; Silverman and Nelson, 2016). The dominating bactericidal portion of the solar spectrum is the UV-B radiation which causes direct (photo-biological) DNA damage (Jagger, 1985). Muela et al. (2000) in fact have shown the activity of $E$. coli exposed to UV-B radiation was reduced with exposure times as short as six hours. In contrast, the response of the E. coli to UV-A and PAR was similar and a longer term exposure was required to reduce the activity. Viruses have also been shown to be inactivated by solar radiation, but to a lesser degree than bacteria (Davies-Colley, 1999; Stinton, 2002).

Sunlight action can be enhanced by environmental factors. Environmental factors include the presence of dissolved organic matter and dissolved oxygen. Dissolved organic matter can attenuate light which decreases inactivation rates. The presence of oxygen is also known to influence the impact of sunlight exposure. For example, the survival of thermotolerant coliforms exposed to sunlight was found to be dependent on the presence of oxygen and increased with decreasing oxygen concentration (Benchokroun et al., 2003). In addition, inactivation of $E$. coli was found to be dependent on dissolved oxygen concentrations and the presence of UV-B wavelength (Kadir and Nelson, 2014). Molecular oxygen promotes solar photoinactivation mediated by endogenous photosensitizers (Muela et al. 2002). In the presence of oxygen, UV radiation generates intracellular byproducts such as reactive hydroxyl radicals, hydrogen peroxide, and superoxide anion radicals, which can cause oxidative stress. The biological targets of these highly reactive oxygen species are a pathogen's DNA, RNA, proteins, and lipids (cytoplasmic membrane) (Cabiscol et al., 2000). In addition, reactions mediated by exogenous photosensitizers can induce lesions in the transport chains in water that contains dissolved organic matter (Muela et al., 2002). However, it is reported that though exogenous photosensitizers played a role in inactivation rates of $E$. faecalis, they did not play an important role in the inactivation of E. coli in similar experiments (Kadir and Nelson, 2014; Nguyen et al. 2015).

\subsection{Sedimentation}

Sedimentation plays an important role in the removal of some microorganisms within the wetland (Gray, 2004). Larger organisms such as protozoan (oo)cysts and helminth eggs can settle by gravity in a free water surface flow constructed wetland. For example, Karim et al. (2004) reported that sediments sampled from a free water surface flow constructed wetland accumulated Giardia and Cryptosporidium (oo)cysts at concentrations which were 2-3 orders of magnitude higher than those in the water column. One study performed in a duckweed pond (not the type of constructed wetland primarily discussed in this chapter) (Falabi et al., 2002) reported removal of $98 \%$ 
Giardia, $89 \%$ of the Cryptosporidium, $63 \%$ of thermotolerant coliforms, and $40 \%$ of coliphages.

As discussed in the Waste Stabilization Pond chapter, bacteria and viruses will not settle unless they are attached to larger and/or denser particles. Only a small percentage of viruses are observed attached to particles in waste stabilization ponds, and the particles they have been found attached to, are reported to be too small to settle (Sobsey and Cooper, 1973; Falabi et al., 2002; Characklis et al., 2005; Symonds et al., 2014). Studies in free water surface flow wetlands support observations made in waste stabilization ponds that bacteria and viruses are effectively removed by sedimentation only if they are attached to larger particles or form larger aggregates. Thus, removal of pathogens should correlate with particle removal (Quinonez-Diaz et al., 2001; Chouinard et al., 2014; Wu et al., 2016).

\subsection{Mechanical Filtration and Media/Plant Importance}

Mechanical filtration has been well described as an appropriate technology for pathogen removal (Maiga et al., 2014; Ushijima et al., 2015). It plays an important role in removal of pathogens in subsurface flow constructed wetlands, particularly by attachment of helminth eggs, larger protozoan (oo)cysts, and bacteria to the filter media (Chouinard et al., 2014). For example, Redder et al. (2010) observed reduction rates of approximately $2 \log _{10}$ for Cryptosporidium oocysts and Giardia cysts in subsurface flow constructed wetlands. Wand et al. (2007) reported an average attachment of $8 \times 10^{6}$ bacteria cells per gram of sand in a column study simulating a vertical flow constructed wetland. Lana et al. (2013) investigated planted and unplanted vertical flow subsurface wetlands receiving a mean influent helminth egg concentration of 61 eggs/L of domestic wastewater. In that study, helminth eggs were removed similarly in the planted and non-planted system (97\% and 96\%, respectively). This suggested that, as expected, mechanical filtration would be the primary removal mechanism of helminths in a subsurface wetland.

The removal of pathogens in a subsurface constructed wetland also depends on the characteristics of the filter bed (e.g., nature of filter media, grain size). In fact, it has been reported that wetlands constructed with peat media removed a larger amount of Salmonella than a wetland constructed with sand media (Pundsack et al., 2001). Ushijima et al. (2013) used a filter bed of fine soil (1-4 mm diameter) in a horizontal subsurface flow wetland and reported removal of $5 \log _{10}$ units for $E$. coli and $3 \log _{10}$ units for MS2 phage, while coarse soil could not remove these microorganisms. In contrast, Redder et al. (2010) showed 2 $\log _{10}$ removal of protozoan parasites (Cryptosporidium oocysts and Giardia cysts) that was dependent of different filter media types (washed sand and clay of different particle sizes) in horizontal and vertical flow subsurface wetlands. This level of removal of protozoan pathogens is supported by other studies (e.g., Hagendorf et al., 2002; Caccio et al., 2013). Redder et al. (2010) also showed that media type and size can have an effect on attachment of some, but not all, pathogens to bed media. Information on how media type impacts microbial fate and transport in subsurface environments can be found elsewhere (e.g., Yates et al., 1988).

The presence of vegetation in constructed wetlands can improve the removal of pathogens by mechanical filtration and adsorption processes. The root-substrate complex and associated biofilm in planted constructed wetlands are reported to have the capacity for mechanical filtration and adsorption of pathogens (Morsy et al., 2007). Viral particles can be removed by adsorption to plant surfaces and roots (Quinonez-Diaz et al., 2001; Nokes et al., 2003); however, adsorption to sediment and suspended particles (dead algal and bacterial cells) may also be important (Nokes et al., 2003). Some bacteria could also attach to plant roots contributing to their removal (Wu et al., 2016). For example, Kadlec and Wallace (2009) reported that in wetland environment, parts of submerged plants and their associated biofilms form "sticky traps" for particles. These biofilms are believed capable of trapping a considerable number of organisms (Stott and Tanner, 2005). Biofilms that occur around rhizosphere have also been shown to support development of bacterial populations that have antibiotic activities which may contribute to pathogen removal (Broadbent et al., 1971). Webber and Legge (2008) have suggested that the biofilms present in a constructed wetland may also facilitate the retention of pathogens through attachment and harboring grazing protozoa in and on the surface of the biofilm region. On the other hand, shading by vegetation will reduce exposure of pathogens to UV light and prevent heating of the water by sunlight, thus decreasing the rate of inactivation (Quinonez-Diaz et al., 2001; Morsy et al., 2007).

Vymazal (2005) demonstrated through a review of sixty studies that free water surface flow constructed wetlands that contained emergent vegetation were more effective in removal of bacteria than systems that were not planted. They reported 95 to $99 \%$ removal of $E$. coli and 80 to $95 \%$ removal of fecal streptococci in free water surface flow wetlands planted with emergent vegetation. They discussed that planted systems can enhance the presence of oxygen and the plants may produce excretions that have antimicrobial properties (Neori et al., 2000).

Previously, Hench et al. (2003) observed greater reduction of thermotolerant coliforms, enterococci, Salmonella, Shigella, Yersinia and coliphage populations in planted subsurface wetlands compared to those lacking vegetation. In this case, the plant roots reach into the subsurface treatment area. In addition, Hill and Sobsey (2001) found that the presence of plants in a horizontal subsurface flow constructed wetland improved the removal of Salmonella when compared to an unplanted unit. However, for vertical flow constructed subsurface wetlands, no significant difference in the removal efficiency was observed of thermotolerant coliforms, E. coli, somatic coliphages, and F-specific bacteriophages for planted and unplanted systems (Torrens et al., 2009; Lana et al, 2013). 


\subsection{Physical-Chemical Factors of Temperature, pH, and Dissolved Oxygen}

As stated in the Waste Stabilization Pond chapter, the most important physical-chemical factors for pathogen inactivation are $\mathrm{pH}$, temperature, and dissolved oxygen. Most bacterial pathogens are vulnerable to high $\mathrm{pH}$, with Vibrio spp. being an exception (Mezrioui et al., 1995). The sanitizing effect of free ammonia $\left(\mathrm{NH}_{3}\right)$, which becomes more available at higher $\mathrm{pH}$, is even more effective at higher temperatures (Decrey et al., 2014; Emmoth et al., 2011; Burge et al., 1983).

Temperature has been shown to play an important role in the reduction of enteric bacteria and viruses in constructed subsurface wetlands (Quinonez-Diaz et al., 2001; Winward et al., 2008). In Germany, Ulrich et al. (2005) found that higher wastewater temperatures in the summer improved pathogen removal performance by approximately $1 \log _{10}$ unit. Weber and Legge (2008) reported that increased temperature will increase predator activity of grazing protozoa. Subsurface wetlands may be cooler than a horizontal subsurface flow constructed wetland during summer months; however, they may provide higher temperatures during low temperature winters in some parts of the world. In some specific situations, there may even be a need to reduce organic loading during the winter (Gray, 2004).

The majority of constructed wetlands have a $\mathrm{pH}$ that ranges between 5.5 and 7.5. However, due to high bacterial nitrification of ammonium in aerobic filter beds and to presence of high natural humic and tannic acids, a very small number of constructed wetlands have reported $\mathrm{pH}$ as low as 3.7 to 4.7 (Pundsack et al., 2001). This low pH was reported to contribute to greater Salmonella removal (Pundsack et al., 2001). importance of dissolved oxygen in pathogen removal in a constructed wetland (e.g., Green et al., 1997) was discussed in a previous subsection on Sunlight and Water Clarity.

\subsection{Other Microbiological Factors}

\subsubsection{Predation}

Constructed wetlands are known to support diverse biota (Vymazal et al., 2001) which includes nematodes, rotifers, and protozoa that can prey on pathogens. Freeliving ciliated protozoa and copepods can be important predators in the removal of Cryptosporidium oocysts (Stott et al., 2001) and bacteria (Wand et al., 2007). Furthermore, the ciliate Paramecium was reported to consume over 100 E. coli per hour (Decamp and Warren, 1998) and another study estimated the grazing rates in the gravel media of a subsurface wetland to be in the order of 49 bacteria/ciliate- hour (Decamp et al., 1999). Morsy et al. (2007) also reported an average Cryptosporidium oocysts predation rate by wetland ciliates of 10 oocysts/ciliate-hour. Protozoa grazing is also reported to have an impact on bacterial community structure in soil microcosms (Ronn et al., 2002).

\subsection{Design, Operation, and Maintenance Guidelines for Pathogen Removal}

The performance of constructed wetlands on pathogen removal depends on a synergistic effect of many environmental, design, and operational factors. However, pathogen and indicator species removal in constructed wetlands is expected to be primarily influenced by the hydraulic loading rate (HLR) (Brix et al., 2003) and thus the hydraulic retention time (HRT) (Vymazal, 2005). In free water surface flow constructed wetlands, longer HRTs are reported to increase pathogen inactivation (e.g., Garcia et al., 2003; Ulrich et al., 2005). This is because of increased exposure to sunlight in zones where there is not extensive plant coverage and more time is allowed for sedimentation, adsorption to organic matter, predation, and the effect of toxins from plants (Diaz et al., 2010).

The HRT depends on the flowrate and the presence of plants, characteristics of the porous media for a subsurface wetland, and the desired water depth for a free water surface flow wetland. In addition, short-circuiting of wastewater flow can lead to lower treatment efficiency because the actual treatment residence time may be less than the theoretical hydraulic retention time. Ulrich et al. (2005) indicated that issues of clogging of inlet pipes in horizontal and vertical flow subsurface constructed wetlands lead to hydraulic short circuiting. Finally, Wu et al. (2016) reported that hydraulic overloading could reduce the removal efficiency of thermotolerant coliforms because of decreased ability of the coliforms to adsorb to the biofilm.

The presence of local animals (domesticated and wild) may introduce pathogens and indicators to a free water surface flow wetland (e.g., E. coli and Salmonella). Moreover, free water surface flow wetlands can be sources of some (but not all) nuisance mosquitoes, some of which have a public health implication (Culex quinquefasciatus) (IWM and IDRCI, 2010). Wetland design and operation can be directly integrate with mosquito control (Russell, 1999; Sarneckis, 2002) if that is an important management objective. It has also been shown that intense precipitation events can dilute microorganism concentrations which will lower removal rates and consequently a wetland's overall performance (Ulrich et al., 2005).

Key factors and strategies that could enhance pathogen removal in different types of constructed wetlands are presented in Table 3. 
Table 3. Summary of key factors and strategies to enhance pathogen removal in constructed wetlands

\begin{tabular}{|c|c|c|c|c|c|}
\hline \multirow{2}{*}{ Factor } & \multirow{2}{*}{$\begin{array}{l}\text { Pathogen removal is } \uparrow \text { enhanced or } \downarrow \\
\text { reduced under the following conditions: }\end{array}$} & \multicolumn{4}{|c|}{ Pathogen Groups Primarily Affected } \\
\hline & & Bacteria & Viruses & Protists & Helminths \\
\hline Sunlight Exposure & $\begin{array}{l}\text { More Sunlight Exposure }=\uparrow \text { Pathogen } \\
\text { Removal in Free Surface Flow Wetland }\end{array}$ & 00 & 000 & & \\
\hline $\begin{array}{l}\text { Water Temperature } \\
\mathrm{pH}\end{array}$ & $\begin{array}{c}\text { Higher Temperature }=\uparrow \text { Pathogen Removal } \\
\text { Higher } \mathrm{pH}=\uparrow \text { Pathogen Removal }\end{array}$ & & 0 & & כ \\
\hline Hydraulic Retention Time & $\begin{array}{c}\text { Longer Retention Time }=\uparrow \text { Pathogen } \\
\text { Removal }\end{array}$ & & 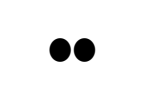 & $\bullet 00$ & 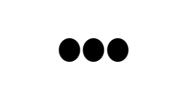 \\
\hline $\begin{array}{l}\text { Presence of Plants that } \\
\text { Increases Shading and Limits } \\
\text { Sunlight Exposure }\end{array}$ & $\begin{array}{c}\text { Plant Shading }=\downarrow \text { Pathogen Removal in Free } \\
\text { Surface Flow Wetland }\end{array}$ & 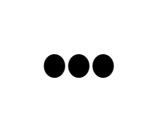 & ค & & • \\
\hline $\begin{array}{l}\text { Presence of Plants } \\
\text { (Mechanisms not Related so } \\
\text { Increased Shading) }\end{array}$ & Plant Mechanisms $=\uparrow$ Pathogen Removal & 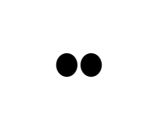 & ๑० & 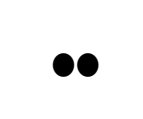 & ? \\
\hline Subsurface Flow & Subsurface Flow $=\uparrow$ Pathogen Removal & & & ○० & 00 \\
\hline Sludge Accumulation & $\begin{array}{c}\text { More Accumulated Sludge }=\downarrow \text { Pathogen } \\
\text { Removal }\end{array}$ & & & & \\
\hline Turbidity & $\begin{array}{c}\text { Greater Turbidity }=\text { Less Sunlight Penetration } \\
=\downarrow \text { Pathogen Removal }\end{array}$ & or & 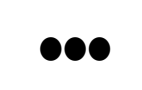 & & 0 \\
\hline Hydraulic Short-Circuiting & $\begin{array}{c}\text { Hydraulic Short-Circuiting }=\downarrow \text { Pathogen } \\
\text { Removal }\end{array}$ & & & & \\
\hline Organic Overloading & Organic Overloading $=\downarrow$ Pathogen Removal & & & & \\
\hline
\end{tabular}

\subsection{Summary of Data on Pathogen Removal in Constructed Wetland Systems}

Pathogen removal in constructed wetlands is influenced by a number of factors including engineering, environmental, and operation and maintenance practices. Factors reported to have the greatest influence on pathogen removal are hydraulic retention time (HRT), hydraulic loading rate (HLR), and the presence of plants (e.g., Brix et al., 2003; Vymazal, 2005). The concept of HRT does not apply for unsaturated media, such as vertical flow subsurface wetlands operated with intermittent feeding (i.e., the wastewater is not occupying all the void spaces). Accordingly, the Figures 9 and 10 were constructed using only data collected for horizontal subsurface flow and free water surface flow constructed wetlands.
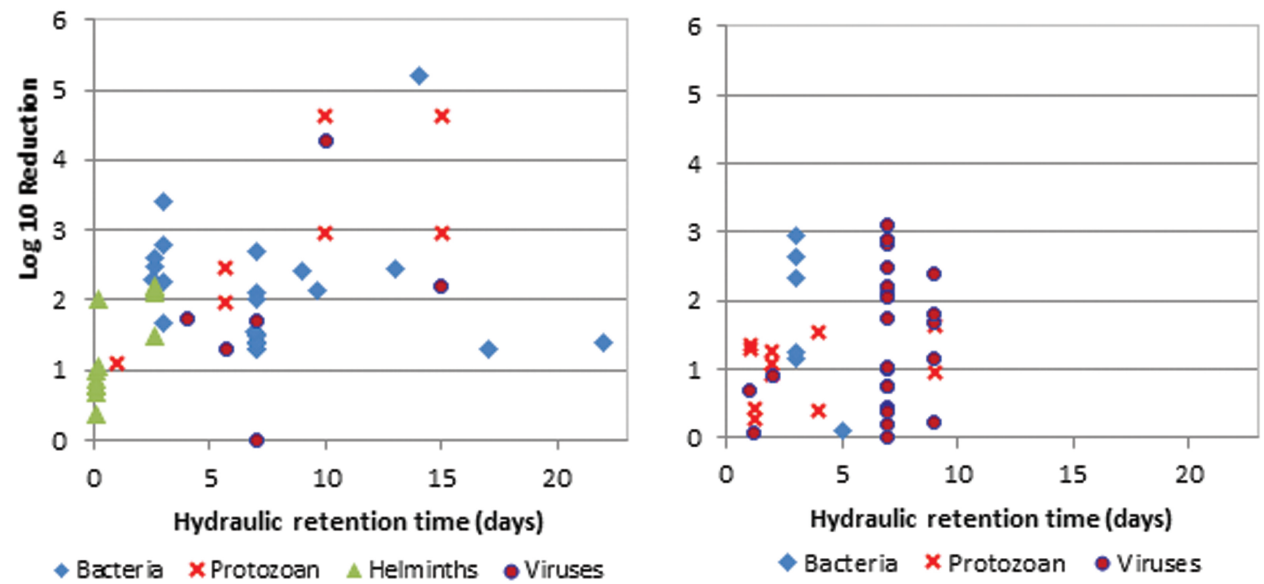

Figure 9. Pathogen removal as a function of hydraulic residence time (HRT) in (a) horizontal subsurface flow constructed wetland and (b) free water surface flow constructed wetland 


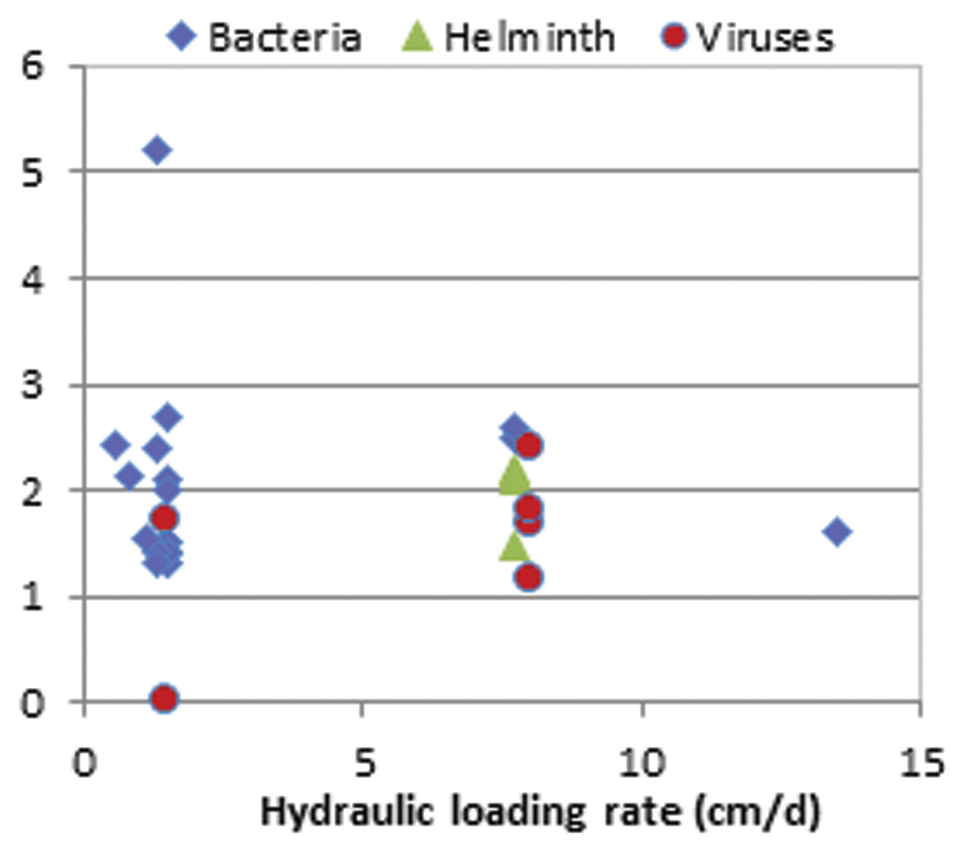

Figure 10. Influence of hydraulic loading rate on pathogen removal in constructed wetlands

The effect of hydraulic retention time (HRT) on pathogen removal is shown in Figures 9a and 9b. These two figures show HRT has an influence on pathogen removal (bacteria, viruses, helminths and protozoan) in horizontal subsurface (Figure 9a) and free water surface flow (Figure 9b) constructed wetlands. The impact appears more pronounced for the helminth and protozoan data (as suggested by information provided previously in Table 3).

Figure 9a shows that for subsurface wetlands, one could expect 1 to $3 \log _{10}$ reduction in pathogens with an HRT of $\leq 10$ days. With an HRT of 10 to 15 days, one might be able to achieve one additional $\log _{10}$ reduction in protozoa concentration. Figure $9 \mathrm{~b}$ shows free water surface flow wetlands are expected to achieve a wide range of removal of bacteria and viruses that can range from less than $1 \log _{10}$ reduction to up to 2 or $3 \log _{10}$ reduction. This supports the conclusions of others (e.g., Nguyen et al., 2015; Silverman et al., 2015) that sunlight inactivation is very important for virus and bacteria reductions and this mechanism may be limited in a free water surface flow constructed wetland that contains emergent plants because of shading of the water by the vegetation. The observations in Figure 9a and 9b are also supported by Wu et al. (2016) who showed that horizontal subsurface flow constructed wetlands typically have a better capacity to remove pathogens than a planted free water surface flow constructed wetlands.

Diaz et al. (2010) studied free water surface flow constructed wetlands and reported that of all the parameters considered, HRT appeared to be the primary factor affecting bacterial indicator removal. However, HRT is not the only factor influencing pathogen fate because in that study and as shown in Figure 9, some studies conducted with longer HRTs had low removal efficiencies of bacteria. This chapter has already discussed that plants may assist or be detrimental to pathogen removal in a constructed wetland. Analysis of data used to generate Figure 9 that was separated by studies where the wetland was vegetated or not vegetated did not provide any insight on how planted or unplanted systems would impact the reduction of pathogens for similar HRT.

Figure 10 shows the impact of hydraulic loading rate (HLR) on pathogen removal. For this figure the data is not sorted by wetland type. Note that contrary to reports by Brix et al. (2003) and others, the data we assembled indicated that pathogen was not influenced by increasing HLR.

\subsection{Summary of Data on Pathogens in Constructed Wetland Sediments}

Constructed wetlands can be used to treat on-site or centralized wastewater. They are typically placed after other sanitation technologies that may include some type of treatment for solids. Even with this pretreatment step, over time, some of the pathogens entering a free water surface flow constructed wetland will accumulate in wetland's bottom sediments. Sedimentation does not necessarily result in the inactivation of pathogens and pathogens may remain viable in sediments. The most durable and persistence pathogens that survive best in sediments are helminths and protozoans. Thus, as discussed in the Waste Stabilization Pond chapter, the recommended treatment method for sediments excavated from a constructed wetland used to treat municipal wastewater should be either burial in a nearby field (to limit human contact), or dewatering in an open field or a constructed sludge drying bed. There the materials should be stored in the sunlight and out of the excessive rain for a minimum of one year 
prior to reuse. Greenhouse solar drying beds may be constructed to help speed up the process by desiccating the material and raising temperatures during the day. The addition of seeds from wetland plants such as Ludwigia spp. can also help accelerate dewatering (Oakley et al., 2012). Lime can also be added to sediments to stabilize the materials and increase the $\mathrm{pH}$ which is known to inactivate pathogens.

\subsection{Conclusions}

Constructed wetlands are a sanitation technology that have not typically been designed for pathogen removal, but instead, have been designed to remove other water quality constituents such as suspended solids, organic matter (BOD/COD) and nutrients (nitrogen and phosphorus). Table 4 provides a summary of typical pathogen removal efficiencies that can be expected in constructed wetlands.
The data summarized in this table was based on constructed wetlands that had hydraulic retention times of primarily $\leq 10$ days and hydraulic loadings rates of $\leq 8$ $\mathrm{cm} /$ day. All types of pathogens (i.e., bacteria, viruses, protozoan and helminths) are expected to be removed in a constructed wetland; however, Table 4 shows that one would expect greater pathogen removal in a subsurface wetland. Figure 9a, Figure 9b, Figure 10, and Table 4 indicate that the efficiency of pathogen removal in full-scale constructed wetland systems can be highly variable, and depends on a number of other factors discussed in Tables 2 and 3). One reason for this is because constructed wetlands include free-floating, subsurface, or planted emergent vegetation (which assists in removing pathogens, but especially other pollutants such as nutrients); thus, the importance of sunlight exposure is minimized in a free water surface flow wetland.

Table 4. Summary of expected $\log 10$ removal of pathogens from wastewater in constructed wetlands

\begin{tabular}{|c|c|}
\hline Free Water Surface Flow Wetland & Subsurface Flow Wetland \\
\hline $\begin{array}{l}1 \text { to } 2 \log _{10} \text { reduction of pathogens can be expected through } \\
\text { proper design and operation. However, bacteria and virus } \\
\text { removal may be }<1 \log _{10} \text { reduction in systems that are } \\
\text { heavily planted with vegetation. This is because constructed } \\
\text { wetlands typically include vegetation (which assists in } \\
\text { removing other pollutants such as nutrients); therefore, the } \\
\text { importance of sunlight exposure in removing viruses and } \\
\text { bacteria is minimized in these systems. }\end{array}$ & $\begin{array}{l}1 \text { to } 2 \log _{10} \text { removal of pathogens can be expected through } \\
\text { proper design and operation. Removal efficiency of } 3 \log _{10} \\
\text { may be achieved for bacteria. One would expect greater } \\
\text { removal for most pathogens in a subsurface wetland } \\
\text { compared to a free water surface flow wetland. }\end{array}$ \\
\hline $\begin{array}{l}\text { Expected } \log _{10} \text { reduction } \\
\text { Bacteria: }<1 \text { to } 2 \\
\text { Viruses: }<1 \text { to } 2 \\
\text { Protozoa: } 1 \text { to } 2 \\
\text { Helminths: } 1 \text { to } 2\end{array}$ & $\begin{array}{c}\text { Expected } \log _{10} \text { reduction } \\
\text { Bacteria: } 1 \text { to } 3 \\
\text { Viruses: } 1 \text { to } 2 \\
\text { Protozoa: } 2 \\
\text { Helminths: } 2\end{array}$ \\
\hline
\end{tabular}




\section{References}

Batty, L.C., Atkin, L. and Manning, D.A.C. (2005). Assessment of the ecological potential of mine-water treatment wetlands using a baseline survey of macroinvertebrate communities. Environmental Pollution. 138, Elsevier. pp. 412-419.

Benchokroun, S., Imziln, B. and Hassani, L. (2003). Solar inactivation of mesophilic Aeromonas by exogenous photooxidation in high-rate algal pond treating waste water. Journal of Applied Microbiology. 94, pp. 531-538. edit

Brix, H., Arias, C.A., Cabello, A. and Johansen, N.H. (2003). Removal of indicator bacteria from municipal wastewater in an experimental two-stage vertical flow constructed wetland system. Water Science and Technology. 48, pp. 35-41.

Broadbent, P., Bakker, K.F. and Waterworth, Y. (1971). Bacteria and actinomycetes antagonistic to fungal root pathogens in Australia soils. Australian Journal of Biological Sciences. 24, pp. 925-944.

Burge, W.D., Cramer, W.N. and Kawata, K. (1983). Effect of heat on virus inactivation by ammonia. Applied and Environmental Microbiology. 46, pp. 446-451.

Burgoon, P.S., Kadlec, R.H. and Henderson, M. (1999). Treatment of potato processing wastewater with engineered natural systems. Water Science and Technology. 40, Elsevier. pp. 211-215.

Cabiscol, E., Tamarit, J. and Rose, J. (2000). Oxidative stress in bacteria and protein damage by reactive oxygen species. International Microbiology. 3, pp. 3-8.

edit

Cacciò, S.M., De Giacomo, M., Aulicino, F.A. and Pozio, E. (2003). Giardia cysts in wastewater treatment plants in Italy. Applied and Environmental Microbiology. 69, pp. 3393-3398.

edit

Calheiros, C.S.C., Rangel, A.O.S.S. and Castro, P.M.L. (2007). Constructed wetland systems vegetated with different plants applied to the treatment of tannery wastewater. Water Research. 41, Elsevier. pp. 1790-1798.

Characklis, G.W., Dilts, M.J., Simmons, O.D., Likirdopulos, C.A., Krometis, L.A.H. and Sobsey, M.D. (2005). Microbial partitioning to settleable particles in stormwater. Water Research. 39, pp. 1773-82. doi: 10.1016/j.watres.2005.03.004. edit

Chouinard, A., Balch, G.C., Jorgensen, S.E., Yates, C.N. and Wootton, B.C. (2014). Tundra wetlands: the treatment of municipal wastewaters. RBC blue water project: performance and operational tools. CWAT, Fleming College. pp. 380.

Crites, R. and Tchobanoglous, G. (1998). Small and Decentralized Wastewater Management Systems. WCB/McGraw-Hill. New York.

Cronk, J.K. (1996). Constructed wetlands to treat wastewater from dairy and swine operations: a review. Agriculture, ecosystems and environment. 58, Elsevier. pp. 97-114.

Davies-Colley, R.J., Craggs, R.J., Park, J. and Nagels, J.W. (2005). Optical characteristics of waste stabilization ponds: recommendations for monitoring. Water Science and Technology. 51, pp. 153-61. 
Davies-Colley, R.J., Craggs, R.J., Park, J., Sukias, J.P.S., Nagels, J.W. and Stott, R. (2005). Virus removal in a pilot-scale 'advanced' pond system as indicated by somatic and F-RNA bacteriophages. Water Science and Technology. 51, pp. 107-10.

Davies-Colley, R.J., Donnison, A.M., Speed, D.J., Ross, C.M. and Nagels, JW.al (1999). Inactivation of faecal indicator microorganisms in waste stabilisation ponds: interactions of environmental factors with sunlight. Water Research. 33, Elsevier. pp. 1220-1230.

Decamp, O. and Warren, A. (1998). Bacterivory in ciliates isolated from constructed wetlands (reed beds) used for wastewater treatment. Water Research. 32, pp. 1989-1996.

Decamp, O., Warren, A. and Sanchez, R. (1999). The role of ciliated protozoa in subsurface flow wetlands and their potential as bioindicators. Water Science and Technology. 40, pp. 91-98.

Decamp, O. and Warren, A. (2000). Investigation of Escherichia coli removal in various designs of subsurface flow wetlands used for wastewater treatment. Ecological Engineering. 14, pp. 293-299. doi: 10.1016/S0925-8574(99)00007-5.

Decrey, L., Kazama, S., Udert, K.M. and Kohn, T. (2014). Ammonia as an in situ sanitizer: inactivation kinetics and mechanisms of the ssRNA virus MS2 by NH3. Environmental science and technology. 49, ACS Publications. pp. $1060-1067$.

Diaz, F.J., O'Geen, A.T. and Dahlgren, R.A. (2010). Efficacy of constructed wetlands for removal of bacterial contamination from agriculture return flows. Agricultural Water Management. 97, pp. 1813-1821.

Emmoth, E., Ottoson, J., Albihn, A., Belák, S. and Vinneraas, B. (2011). Ammonia disinfection of hatchery waste for elimination of single-stranded RNA viruses. Applied and Environmental Microbiology. 77, pp. 3960-3966.

Falabi, J.A., Gerba, C.P. and Karpiscak, M.M. (2002). Giardia and Cryptosporidium removal from waste-water by a duckweed (Lemna gibba L.) covered pond. Letters in Applied Microbiology. 34, pp. 384-387.

Fuchs, V.J., Gierke, J.S. and,. (2012). Laboratory investigation of ammonium and nitrate removal in vertical flow regimes in planted and unplanted wetland columns. Journal of Environmental Engineering. 138, pp. 1227-1230.

Garcia, J., Vivar, J., Aromir, M. and Mujeriego, R. (2003). Role of hydraulic retention time and granular medium in microbial removal in tertiary treatment reed beds. Water Research. 37, pp. 2645-2653.

Gerba, C.P. (2000). Assessment of enteric pathogen shedding during recreational activity and its impact on water quality. Quantitative Microbiology. pp. 55-68.

Gray, N.F. (2004). Biology of wastewater treatment. Series in Environmental Science and Management. 2nd ed. Imperial College Press. London.

Green, M.B., Griffin, P., Seabridge, J.K. and Dhobie, D. (1997). Removal of bacteria in subsurface flow wetlands. Water Science and Technology. 35, pp. 109-116.

Hagendorf, U., Bartocha, W., Diehl, K., Feuerpfeil, I., Hummel, A., Lopez-Pila, J. et al. (2002). Mikrobiologische 
Untersuchungen zur seuchenhygienischen Bewertung naturnaher Abwasserbehandlungsanlagen. Wasser Boden Luft, Heft 3.

Headley, T.R., Davidson, L. and Yeomans, A. (2004). Removal of ammonia-N from landfill leachate by vertical flow wetland: a pilot study. In Proceedings of 9th International Conference Wetland systems for water pollution control. ASTEE. Lyon, France. pp. 143-150.

Hench, K.R., Bissonnette, G.K., Sextone, A.J., Coleman, J.G., Garbutt, K. and Skousen, J.G. (2003). Fate of physical, chemical and microbial contaminants in domestic wastewater following treatment by small constructed wetlands. Water Research. 37, pp. 921-927.

Hill, V.R. and Sobsey, M.D. (2001). Removal of Salmonella and microbial indicators in constructed wetlands treating swine wastewater. Water Science and Technology. 44, pp. 215-222.

International Water Management Institute, International Development Research Centre (2010). Wastewater irrigation and health: assessing and mitigating risk in low-income countries. (Drechsel, P., Scott, C.A., Raschid-Sally, L., Redwood, M. and Bahri, A., ed.). Earthscan. London, UK.

ITRC (2003). Technical and Regulatory Guidance for Constructed Treatment Wetlands. WTLND-1. Interstate Technology Regulatory Council Wetlands Team, USA. Washington, DC.

Jagger, J. (1985). Solar-UV Actions on Living Cells. Praeger Publishers. New York.

Kadir, K. and Nelson, K.L. (2014). Sunlight mediated inactivation mechanisms of Enterococcus faecalis and Escherichia coli in clear water versus waste stabilization pond water. Water Research. 50, pp. 307-317.

Kadlec, R.H. and Knight, R.L. (1996). Treatment Wetlands. Lewis Publishers. Boca Raton, FL.

Kadlec, R.H. and Wallace, S.D. (2009). Treatment wetlands. 2nd editio ed. CRC Press, Taylor and Francis Group, LLC. London, UK. pp. 965.

Kantawanichkul, S. and Somprasert, S. (2005). Using a compact combined constructed wetland system to treat agricultural wastewater with high nitrogen. Water Science and Technology. 51, pp. 47-53.

Karim, M.R., Manshadi, F.D., Karpiscak, M.M. and Gerba, C.P. (2004). The persistence and removal of enteric pathogens in constructed wetlands. Water Research. 38, pp. 1831-1837.

Kohn, T., Mattle, M.J., Minella, M. and Vione, D. (2016). A modeling approach to estimate the solar disinfection of viral indicator organisms in waste stabilization ponds and surface waters. Water Research. 88, pp. 912-922. doi: 10.1016/j.watres.2015.11.022.

Koottatep, T., Surinkul, N., Polprasert, C., Kamal, A.S.M., Koné, D., Montangero, A. et al. (2005). Treatment of septage in constructed wetlands in tropical climate: Lessons learnt from seven years of operation. Water Science and Technology. 51, pp. 119-126. 
Kuschk, P., Wiessner, A., Seeger, E.M., Kastner, M., Kappelmeyer, U., Paredes, D. et al. (2012). The status of research on constructed wetlands. Environmental and Food Safety and Security for South-East Europe and Ukraine. Vitale K.( ed. Nato science for peace and security series C: Environmental security. Springer science + business media B.V. pp. 155-171.

Lana, L.C.O., Moraes, D.C., von Sperling, M., Morato, M.L.N., Vasconcellos, G.R., Paraense, M.O. et al. (2013). Performance of a single stage vertical flow constructed wetland system treating raw domestic sewage in Brazil. Water Science and Technology. 68, pp. 1599-1606.

Maiga, Y., Moyenga, D., Nikiema, B.C., Ushijima, K., Maiga, A.H. and Funamizu, N. (2014). Designing slanted soil system for greywater treatment for irrigation purposes in rural area of arid regions. Environmental Technology. 35, pp. 3020-3027.

Mattle, M.J., Vione, D. and Kohn, T. (2014). Conceptual model and experimental framework to determine the contributions of direct and indirect photoreactions to the solar disinfection of MS2, phiX174, and adenovirus. Environmental Science and Technology. 49, pp. 334-342.

Mezrioui, N., Oufdou, K. and Baleux, B. (1995). Dynamics of non-O1 Vibrio cholerae and fecal coliforms in experimental stabilization ponds in the arid region of Marrakesh, Morocco, and the effect of $\mathrm{pH}$, temperature, and sunlight on their experimental survival. Canadian Journal of Microbiology. 41, pp. 489-498.

Mihelcic, J.R., Myre, E.A., Fry, L.M., Phillips, L.D. and Barkdoll, B.D. (2009). Field Guide in Environmental Engineering for Development Workers: Water, Sanitation, Indoor Air. American Society of Civil Engineers (ASCE) Press. Reston, VA.

Mihelcic, J.R. and Zimmerman, J.B. (2014). Environmental Engineering: Fundamentals, Sustainability, Design. 2nd ed. John Wiley and Sons, Inc. New York.

Morel, A. and Diener, S. (2006). Greywater management in low and middle-income countries, review of different treatment systems for households and neighbourhood. Sandec report No. 14/06. Swiss Federal Institute of Aquatic Science and Technology (Eawag). Dübendorf, Switzerland. pp. 107.

Muela, A., Garcia-Bringas, J.M., Arana, I. and Barcina, I. (2000). The effect of similated solar radiation on Escherichia coli: the relative roles of UV-B, UV-A and photosynthetically active radiation. Microbial Ecology. 39, pp. 65-71.

Muela, A., Garcia-Bringas, J.M., Seco, C., Arana, I. and Barcina, I. (2002). Participation of oxygen and role of exogenous and endogenous sensitizers in the photoinactivation of Escherichia coli by photosynthetically radiation, UV-A, UV-B. Microbial Ecology. 44, pp. 354-364.

Neori, A., Reddy, K.R., H Koncalava, C. and Agami, M. (2000). Bioactive chemicals and biological-biochemical activities and their functions in rhizospheres of wetland plants. The Botanical Review. 66, pp. 351-378.

Nguyen, M.T., Jasper, J.T., Boehm, A.B. and Nelson, K.L. (2015). Sunlight inactivation of fecal indicator bacteria in openwater unit process treatment wetlands: Modeling endogenous and exogenous inactivation rates. Water Research. 83, pp. 282-292. doi: 10.1016/j.watres.2015.06.043.

Nokes, R.L., Gerba, C.P. and Karpiscak, M.M. (2003). Microbial water quality improvement by small scale on-site subsurface wetland treatment. Journal of Environmental Science and Health. 38, pp. 1849-1855. 
Oakley, S.M., Mendonça, L.C. and Mendonça, S.R. (2012). Sludge removal from primary wastewater stabilization ponds with excessive accumulation: a sustainable method for developing regions. Journal of Water, Sanitation and Hygiene for Development. 2, pp. 68. doi: 10.2166/washdev.2012.093.

Pundsack, J., Axler, R., Hicks, R., Henneck, J., Nordman, D. and McCarthy, B. (2001). Seasonal pathogen removal by alternative on-site wastewater systems. Water Environment Research. 73, pp. 204-212.

Quinonez-Diaz, M.D.J., Karpisck, M.M., Ellman, E.D. and Gerba, C.P. (2001). Removal of pathogenic and indicator microorganisms by a constructed wetland receiving untreated domestic wastewater. Journal of Environmental Science and Health. 36, pp. 1311-1320.

Redder, A., Dürr, M., Daeschlein, G., Baeder-Bederski, O., Koch, C., Müller, R. et al. (2010). Constructed wetlands-Are they safe in reducing protozoan parasites?. International Journal of Hygiene and Environmental Health. 2013, pp. 72-77.

Ronn, R., McCaig, A.E., Griffiths, B.S. and Prosser, J.I. (2002). Impact of Protozoan Grazing on Bacterial Community Structure in Soil Microcosms. Applied and Environmental Microbiology. 68, pp. 6094-6105.

Russell, R.C. (1999). Constructed wetlands and mosquitoes: Health hazards and management options-An Australian perspective. Ecological Engineering. 12, pp. 107-124.

Sarneckis, K. (2002). Mosquitos in Constructed Wetlands. Environmental Protection Authority. Adelaide, South Africa.

Silverman, A.I., Nguyen, M.T., Schilling, I.E., Wenk, J. and Nelson, K.L. (2015). Sunlight inactivation of viruses in openwater unit process treatment wetlands: modeling endogenous and exogenous inactivation rates. Environmental Science and Technology. 49, pp. 2757-66. doi: 10.1021/es5049754.

Silverman, A.I., Nguyen, M.T., Schilling, I.E., Wenk, J. and Nelson, K.L. (2015). Sunlight inactivation of viruses in openwater unit process treatment wetlands: modeling endogenous and exogenous inactivation rates. Environmental Science and Technology. 49, pp. 2757-2766.

Silverman, A.I. and Nelson, K.L. (2016). Modeling the Endogenous Sunlight Inactivation Rates of Laboratory Strain and Wastewater E. coli and Enterococci Using Biological Weighting Functions. Environmental Science and Technology. pp. acs.est.6b03721. doi: 10.1021/acs.est.6b03721.

Silverman, A.I., Peterson, B.M., Boehm, A.B., McNeill, K. and Nelson, K.L. (2013). Sunlight inactivation of human viruses and bacteriophages in coastal waters containing natural photosensitizers. Environmental Science and Technology. 47, pp. 1870-8. doi: 10.1021/es3036913.

Sinton, L.W., Hall, C.H., Lynch, P.A. and Davies-Colley, R.J. (2002). Sunlight inactivation of fecal indicator bacteria and bacteriophages from waste stabilization pond effluent in fresh and saline waters. Applied and Environmental Microbiology. 68, pp. 1122-31.

Sobsey, M.D. and Cooper, R.C. (1973). Enteric virus survival in algal-bacterial wastewater treatment systems-I. Water Research. 7, pp. 669-685. doi: 10.1016/0043-1354(73)90085-7.

Sperling, V. (2007). Wastewater Characteristics, Treatment and Disposal, Volume I of Biological Wastewater Treatment. IWA Publishing,. London, UK. 
Stewart, E. (2005). Evaluation of septic tank and subsurface flow wetland for Jamaican public school sewage treatment.

Stott, R., May, E., Matsuishita, E. and Warren, A. (2001). Protozoan predation as a mechanism for the removal of Cryptosporidium oocysts from wastewater in constructed wetlands. Water Science and Technology. 44, pp. 191-198.

Stott, R. and Tanner, C. (2005). Influence of biofilm on removal of surrogate faecal microbes in a constructed wetland and maturation pond. Water Science and Technology. 51, pp. 315-322.

Symonds, E.M., Verbyla, M.E., Lukasik, J.O., Kafle, R.C., Breitbart, M. and Mihelcic, J.R. (2014). A case study of enteric virus removal and insights into the associated risk of water reuse for two wastewater treatment pond systems in Bolivia. Water Research. 65, doi: 10.1016/j.watres.2014.07.032.

Tanner, C.C., Nguyen, M.L. and Sukias, J.P.S. (2005). Nutrient removal by a constructed wetland treating subsurface drainage from a grazed dairy pasture. Agriculture, Ecosystems and Environment. 105, pp. 145-162.

Tilley, E., Ulrich, L., Lüthi, C., Reymond, P. and Zürrbrugg, C. (2014). Compendium of Sanitation Systems and Technologies - 2nd Revised Edition. Swiss Federal Institute of Aquatic Science and Technology (Eawag). Dübendorf, Switzerland. pp. 180.

Torrens, A., Molle, P., Boutin, C. and Salgot, M. (2009). Removal of bacterial and viral indicators in vertical flow constructed wetlands and intermittent sand filters. Desalination. 246, pp. 169-178.

Ulrich, H., Klaus, D., Irmgard, F., Annette, H., Juan, L.P. and Regine, S. (2005). Microbiological investigations for sanitary assessment of wastewater treated in constructed wetlands. Water Research. 39, pp. 4849-4858.

USEPA (1988). Design Manual: Constructed wetlands and aquatic plant systems for municipal wastewater treatment. EPA/625/1-88/022. Center for Environmental Research. Cincinnati, OH.

Ushijima, K., Ito, K.N., Ito, R. and Funamizu, N. (2013). Greywater treatment by slanted soil system. Ecological Engineering. 50, pp. 62-68.

Ushijima, K., Tanaka, E., Suzuki, L.Y., Hijikata, N., Funamizu, N. and Ito, R. (2015). Greywater treatment by the slanted soil system with unsorted soil media. Environmental Technology. 36, pp. 2603-2609.

Vymazal, J. (2005). Removal of enteric bacteria in constructed treatment wetlands with emergent macrophytes: A review. Journal of Environmental Science and Health. 40, pp. 1355-1367.

Vymazal, J. and Kröpfelová, L. (2008). Wastewater Treatment in Constructed Wetlands with Horizontal Sub-Surface Flow. Springer. Dodrecht, The Netherlands.

Vymazal, J., Sládeek, V. and Stach, J. (2001). Biota participating in wastewater treatment in a horizontal flow constructed wetland. Water Science and Technology. 44, pp. 211-214. 
Wand, H., Vacca, G., Kuschk, P., Kruger, M. and Kastner, M. (2007). Removal of bacteria by filtration in planted and nonplanted sand columns. Water Research. 41, pp. 159-167.

Webber, K.P., Legge, R.L. and Russo, R.E. (2008). Pathogen removal in constructed wetkands. Wetlands: Ecology, Conservation and Restoration. Nova Science Publisher, Inc.

Weber, K.P. and Legge, R.L. (2008). Pathogen Removal in Constructed Wetlands. Wetlands: Ecology, Conservation and Restoration. pp. 177-211.

Wendel, HE.Wright, Downs, J.A. and,. (2011). Assessing equitable access to urban green space: the role of engineered water infrastructure. Environmental Science and Technology. 45(16), pp. 728-6734.

Williams, J.B., Zambrano, D., Ford, M.G., May, E. and Butler, J.E. (1999). Constructed wetlands for wastewater treatment in Colombia. Water Sci. Technol. 40, pp. 217-223.

Winward, G.P., Avery, L.M., Frazer-Williams, R., Pidou, M., Jeffrey, P., Stephenson, T. et al. (2008). A study of the microbial quality of greywater and an evaluation of treatment technologies for reuse. Ecol. Eng. 32, pp. 187-197.

Wu, S., Carvalho, P.N., Müller, J.A., Manoj, V.R. and Dong, R. (2016). Sanitation in constructed wetlands: a review on the removal of human pathogens and fecal indicators. The Science of the Total Environment. 541, pp. 8-22.

Wu, S., Carvalho, P.N., Müller, J.A., Manoj, V.Remony and Dong, R. (2016). Sanitation in constructed wetlands: A review on the removal of human pathogens and fecal indicators. Science of The Total Environment. 541, pp. 8-22. doi: 10.1016/j.scitotenv.2015.09.047.

Yates, M.V., Yates, S.R. and Gerba, C.P. (1988). Modeling microbial fate in the subsurface environment. Critical Reviews in Environmental Control. 17(4), pp. 307-344. 